\title{
Flight of Leaves: Creation of Worldly Space
}

\author{
Bo Sun Kim
}

Dr. Bo Sun Kim is a faculty member in the School of Early Childhood Education and Studies at Capilano University, British Columbia, Canada. She is also a pedagogical facilitator in early childhood institutions in British Columbia, working closely with educators and children. Her professional interests focus on children's ideas and perspectives through their narratives and artistic expressions. Her work engages with postmodern theories, poststructural theorists Gilles Deleuze and Félix Guattari, and the philosophical foundations of the Reggio Emilia approach to early childhood education. She is committed to engaging in theorizing the idea of children's participation in early childhood curriculum and broadening understanding of how children can create their own pathways to learning. Email: bosunkim@capilanou.ca

This case study presents (1) children's learning as continual engagement with phenomena and people, and (2) learners and the world as entangled becomings. In particular, the flight of leaves experiment shows the process of how thoughts were created through encounters and relations; how the children becamewith drawings, experiments, each other, and material realities; and how the teacher and the researcher responded to and became entangled in a pedagogical relationship with children and material realities.

Key words: Reggio Emilia; early childhood curriculum; pedagogy of listening; teacher education; experimentation; rhizome
The schools of Reggio Emilia have inspired early childhood educators all over the world to reimagine their beliefs about young children and childhood. Educators who have visited or studied the schools recognize the educational potential of the Reggio Emilia approach for children's intellectual, creative, and social competence and for making strong links with parents, teachers, and the community. Educators have become intrigued with the Reggio Emilia philosophy because it seems like a natural extension of the philosophy already prevalent in many early childhood practices. For example, Jeanne Goldhaber (2008) writes that "it is perhaps ironic that we had to go cross the Atlantic to rediscover [John] Dewey" (p. 179), who argued that good schooling based on inquiry is fundamental to the cultivation and maintenance of a democracy.

Goldhaber (2008) argues that we need to recognize our own cultural history so we can question our values and recover "our own educational legacy" (p. 179). Reggio schools are constantly evolving in ways that continue to reflect their history, culture, and social values even as these are changing. The ideas of Reggio Emilia inspire us to see our children's competencies and richness in light of our own values and hopes for the future. They call for a different way to approach learning, recognizing the importance of making connections and interacting with a world that is constantly becoming, unfolding, and in motion around us.

Learning in Reggio Emilia starts from a different logic of knowledge, one with no predefined progression toward a predestined end (Dahlberg \& Moss, 2009). From this perspective, learning as a process of creating meaning and knowledge construction is described as "a tangle of spaghetti-with no beginning or end, no linear progression but always open to new possibilities" (Edwards et al., 2012, p. 156). This metaphorical phrase is very similar to Gilles Deleuze and Félix Guattari’s (1987) rhizome concept. Both concepts, a tangle of spaghetti and rhizome, emphasize that learning does not proceed in a linear way, and both place encounters and relationships at the centre of learning processes. Learning is not seen as a process of moving forward with understandings in a linear and predictable way. Rather, understandings are constructed through a dynamic process involving the uncertainty and chance that arise in relationships with others and grow in many directions (Moss \& Petrie, 2002). The 
philosophical characteristics of the Reggio Emilia approach put children's ideas, interests, and relationships at the centre of their curriculum (Edwards, Gandini, \& Forman, 2012), valuing children's rights to be listened to and to be recognized social actors in the community (Dahlberg et al., 2013; Rinaldi, 2006). This philosophy starts from a novel image of the child (Dahlberg \& Moss, 2005), or what Loris Malaguzzi (1998) described as a "rich child," an active participant and creator of knowledge, identities, and culture; this philosophy views children through their relations with others and always within a particular context. This image of the child is also related to the image of an educator who is a learner, a researcher, a critical thinker, and a reflective practitioner (Malaguzzi, 1998). Further, educational institutions are understood as places of encounter and as sites of ethical practices, rather than as places that exist primarily for the transmission of knowledge (Dahlberg \& Moss, 2005). Both the principles and practices of the Reggio Emilia approach have been a source of inspiration for many schools in BC and elsewhere in Canada, including the centre involved in this study. Thinking with Reggio Emilia philosophy, this study delves into learning as continual engagement with phenomena and people, learners and the world as entangled becomings, and curriculum as an ongoing process always in the making / in motion through connections, constant change, and reciprocity, similar to a rhizome (Deleuze \& Guattari, 1987).

\section{Conceptual framework}

\section{Reggio Emilia inspirations}

Progettazione. In Reggio Emilia, the relationships between children and between children and educators become a context in which the coconstruction of theories, interpretations, and understandings of reality can take place (Rinaldi, 1998, 2006). Based on this idea, the Reggio educators created their own ways of planning curricula, in which the teachers laid out general educational objectives but did not formulate specific goals for each project or activity in advance (Edwards et al., 2012; Rinaldi; 2006). Instead, teachers generated hypotheses about what might happen or emerge based on their knowledge of the children and of previous experiences. In the Reggio approach, educational objectives are flexible and are adapted to the needs and interests of the children. This type of planning is called progettazione, the Italian term used by Reggio Emilia educators. In the English-speaking world, it is called "emergent curriculum, projected curriculum, or integrated curriculum ... an overall way in which the Reggio teachers plan and work with children" (Rinaldi, 2006, p. xi). According to Carla Rinaldi (2006), "progettazione is a strategy, a daily practice of observation-interpretation-documentation" (p. 206). The goal is to support the child to make choices, communicate those choices, and receive feedback from others. Rinaldi (2006) states that "children who grow up together at school seek the opinions of their friends and stimulate their friends to express their own point of view" (p. 206). In this context, the role of the teacher is to support and stimulate cognitive and social dynamics while they are in progress. Rinaldi (2006) explains, "Instead of formal teaching of a predetermined curriculum (writing, reading, counting, etc.) to be evaluated using some testing procedure, both teachers and children document their own daily activities and learning in symbolic systems with which they are comfortable" (p. 206). The teachers' observations and documentation are taken to colleagues for group reflection. Teachers' documentation stimulates teachers' self-reflection and produces discussion and debate among the group of colleagues. Ideas exchanged among colleagues are as important as those exchanged among the children. The group discussions allow for revision of the teachers' thoughts and hypotheses about the children and their interactions with them. Therefore, "progettazione is a way of thinking, a strategy for creating relations" (Gandini \& Kaminsky, 2006, p. 133). Argument and conflict play a primary role in this system, as progettazione brings out the important parts of individual thoughts and gives new meaning to the knowledge-building process. This is because knowledge develops much more within a context of diversity than within a context of homogeneity. In other words, the educational institution in Reggio Emilia is based on the premise that knowledge is a coconstructed and socially negotiated product that occurs within a historical, cultural, and political context (Malaguzzi, 1998). It emphasizes 
the role of a child's cultural, social, and physical environment in the development of an educational curriculum.

Thus, progettazione is carried out in dialogue between children and educators. This learning is different from "old stereotypes that derive from a pedagogy and practice ... which attempted to pour ideas into teachers to shape them, so that they could, in turn, pour ideas into children" (Gandini \& Kaminsky, 2000, p. 133).

Pedagogy of relationships. The emphasis in the educational approach of Reggio Emilia is placed on seeing each child in relation to other children, teachers, parents, their own history, and the societal and cultural surroundings. The child, from a very early age, is a communicative individual (Malaguzzi, 1998). If we are interested, as teachers and researchers, in foregrounding relationships and communication, we need to listen to the ideas, questions, concerns, and preoccupations of children. We need to make meaning from what is said through their spontaneous conversations, without imposing preconceived ideas of what is correct or valid (Rinaldi, 2006). Reggio educators believe that pedagogy and the pedagogical environment need to be constructed with a view to stimulating children's own activities and the possibilities for them to communicate their experiences to others. Through communication, children can discuss, make choices, argue for their choices, and become active participants in their own learning processes (Rinaldi, 2006). Thus, working in a small group context is essential:

It is a reciprocal relationship that creates a strong sense of solidarity and fosters organisational dynamics from which difference can emerge, and these differences in turn generate extremely significant acts of negotiation and exchanges. The relationships between children become a context in which the co-construction of theories, interpretation and understandings of reality can take place. (Rinaldi, 2006, p. 127)

Relationships, communication, and interactions support this philosophical underpinning. Rinaldi (2006) argues that "the relationships between children offer opportunities to lend and borrow ideas, whether the teacher is directly present or not, and for cognitive conflict, imitation and generosity" (p. 127). In addition, the teacher must establish a personal relationship with each child and ground this relationship in the social system of the school. Rinaldi also argues that "to understand the child is a long and difficult job that we can only learn by working along with children, and this also means understanding ourselves in a new and different way" (pp. 127-128). Thus, children in Reggio schools are placed within the same class group for three years to promote the development of strong relationships among children, families, and teachers. Reciprocal interactions between children and the teachers in the course of creating knowledge are valued and encouraged because they contribute to a sense of community within the larger school setting (Edwards et al., 2012).

The role of the teachers as researchers and co-learners is evident when children and teachers engage in collaborative learning during a project. Rinaldi (2006) writes: "The school must be a place where the symbolic and value systems of the culture and the society are experienced, interpreted, created, and recreated by children and adults together" (p. 128). In this context, a teacher eschews a passive approach to knowledge; instead, he or she welcomes children's different theories and ideas and creates a space where teachers and children research together. Cooperative learning and the commitment to a cordial and collegial classroom environment are characteristics of the Reggio Emilia approach (Edwards et al., 2012). If one believes that children have their own ideas, perspectives, and interpretations and are protagonists in learning processes, then, as Rinaldi (2006) argues, the most important verb in educational dialogue is no longer to talk, but to listen. Learning is no longer seen as knowledge acquisition or as a linear progression. Instead, knowledge, identity, and culture are constituted and reconstituted in relation to others. Knowledge is no longer viewed as an accumulation and reproduction of facts but as an open-ended conversation in which neither agreement nor a final truth are sought (Dahlberg et al., 2013). This approach could be called a pedagogy of relationships, in which children are understood as active participants in constructing 
their knowledge through connectivity, continuity, and reciprocity; this pedagogical stance is central to the Reggio Emilia approach. It calls for different ways of understanding knowledge and thinking, beginning with the image of knowledge as a rhizome (Deleuze \& Guattari, 1987). The rhizome grows in all directions with no beginning and no end but always in the spaces between. This image suggests multiplicity, connections, and heterogeneity. Thoughts and concepts are viewed as creations that emerge from encounters with provocation and difference.

\section{The concept of the rhizome}

Recently, the work of Deleuze and Guattari has received attention in early childhood education (Dahlberg \& Moss, $2005,2009)$. Of particular relevance to this study is Deleuze and Guattari's philosophical concepts that account for thoughts and experimentation in early childhood learning. For Deleuze and Guattari (1987), the rhizome suggests a particular way of thinking, what they call nomadic thinking, that challenges us to embrace the unpredictability and uncontrollability of life. They borrowed the notion of the rhizome from biology; Semetsky (2007) explains: "As a symbol for unlimited growth through the multitude of its own transformations, rhizome is contrasted with a tree that symbolizes the linear and sequential, 'arborescent' reasoning rooted in finite knowledge" (p. 198). A rhizome, such as a mushroom or crabgrass, spreads, without a central root, a spot of origin. This growth habit is different from that of a tree or a root, which, as Deleuze and Guattari explain, "plots a point, fixes an order" (p. 7). The rhizome shows another way of travelling and moving: "proceeding from the middle, through the middle, coming and going rather than starting and finishing" (Deleuze \& Guattari, 1987, p. 25). The central principles of the rhizome concept are connection, heterogeneity, multiplicity, asignifying rupture, and cartography/multiple entryways. Deleuze and Guattari further distinguish the tree and rhizome metaphors by contrasting notions of tracings (decalcomania) and maps (cartography). Yan Zhang (2012) explains:

A tracing is a reproduction of the world based on existing striated structures. In contrast, "the map is open and connectable in all of its dimensions; it is detachable, reversible, susceptible to constant modification. It can be torn, reversed, adapted, to any kind of mounting, reworked by an individual, group, or social formation (Deleuze \& Guattari, 1987, p. 12). An essential characteristic of a map is that "it always has multiple entryways" (Deleuze \& Guattari, p. 12). (p. 32)

Deleuze and Guattari use this symbol of rootlessness, Duckworth (2009) explains, because it resists "the traditional, rational and logical approach to knowledge" (para. 1). Often the traditional approach to knowledge acquisition is represented as growing from roots, like a tree. In contrast, Deleuze and Guattari (1987) explained that the rhizome "has neither beginning nor end, but always a middle (milieu) from which it grows and which it overspills" (p. 21):

A plateau is always in the middle, not at the beginning or the end. A rhizome is made of plateaus: a continuous, self-vibrating region of intensities whose development avoids any orientation toward a culmination point or external end. (pp. 21-22)

Deleuze and Guattari (1987) employed the rhizome metaphor to conceptualize networks in knowledge creation as dynamic entities. When applied to early childhood education, the concept of rhizome in teaching and learning suggests an alternative to models with predetermined outcomes and homogeneous assessments (Olsson, 2009). In this regard, the rhizomatic way of thinking and learning as conceptualized by Deleuze and Guattari can be useful for reconceptualizing curriculum for young children as emergent and relational. The rhizome metaphor contests traditional cause and effect relationships and creates a space for supporting and constructing new and shifting knowledge creation in early childhood learning environments (Olsson, 2009). In terms of learning, rhizomes represent multiplicities of connections, including connections between ideas, experiences, and encounters within the environment, perspectives, and so on. A multiplicity of interconnected thoughts goes off in all directions, so 
linearity and progression are no longer applicable or useful notions with any explanatory power. Thus, as Gunilla Dahlberg and Peter Moss (2009) assert, the rhizome as a metaphor offers the possibility of resisting normalizing practices. Instead, the metaphor opens our consciousness to new ways of relating to young children's participation and learning, and these become both challenging and transformative.

\section{Transcendental empiricism}

Deleuze (1994) considered thought as experimentation: To think, he wrote, "is to experiment, but experimentation is always that which is in the process of coming about - the new, remarkable, and interesting - which replace the appearance of truth and which are more demanding" (p. 111). Liselott Olsson (2009) explains that this philosophy accounts for "the unstableness and continuous production of thought and practice" and "accounts for thoughts as created through encounters and relations" (pp. 27-28). A thought that creates itself as it moves through encounters is looking for that which is unfamiliar and unexpected (Deleuze \& Guattari, 1994). Deleuze (1994, as cited in Olsson, 2009) introduced empiricism into an image of thought, whereby thought "no longer functions through recognition and representation but rather through encounter, connections and assemblages" (p. 42). It is thinking that "constructs and experiments through making new connections in a pragmatic way" (Olsson, 2009, p. 43). Deleuze and Guattari (1987) argued that transcendental empiricism is not the same thing as transcendence; the latter is that which attempts to go beyond or above what we can experience. In other words, events will make sense to us if we experience the difference that makes each event singularly important in practice.

Similarly, Bruce Baugh (2010) argues that "we experiment when we do not know what the result will be and have no preconceptions concerning what it should be. Thus, experiment is inseparable from innovation and discovery" (p. 93). A thought that creates itself as it moves through encounters and relations, as suggested by Deleuze and Guattari, helps explain how children's new ideas, concepts, and stories can be created through connections with one another in this study.

In addition, Deleuze (1988) argued that experimentation is necessary to reveal "what a body or mind can do, in a given encounter, arrangement or combination of the affects a body is capable of" (p. 125). The compatibility or incompatibility of different elements and bodies, and the effect of their combination, can only be verified through experience; we have no a priori knowledge of them through principles or axioms. Experience is what affects us and is therefore affective. For Deleuze, thinking enriched with affect is always experimental rather than focused on discovering an eternal truth. Thus, experimentation proceeds "flow by flow" (p. 125) using different techniques and materials without any set rules. One never knows in advance; if one did, it would not be an experiment.

For Deleuze (1994), the creative process of learning is as much a method of invention. Learning cannot take place as representation (Semetsky, 2007), because this would be the reproduction of knowledge. Deleuze argued that it is the difference embedded in real experience that prevents any prior recognition; the singularity of a situation creates an experiment with the new and something unfamiliar (Semetsky, 2007). In this regard, transcendental empiricism accounts for its own inventiveness, with practices taking place within a relationship of children, materials, surroundings, and experimentation in this study.

After exploring the philosophical concepts of Deleuze and Guattari and the principles behind the Reggio Emilia approach, I recognized common elements in these two ways of thinking about learning. In both theories, knowledge is seen as becoming and transforming with unexpected connections and relations that can be viewed both as rhizomes and as a tangle of spaghetti. The progettazione in the Reggio Emilia approach and Deleuze and Guattari's preoccupation with transcendental empiricism and the rhizome demonstrate that both approaches value encounters, relations, innovations, inventions, and otherness in learning. 


\section{Background to the study}

The Italian Reggio Emilia approach to early childhood education is neither a recipe nor an easily convertible solution for school reform in any other country (Rinaldi, 2006; New, 2007). Rebecca New (2007) asserts that there is not only danger in trying to imitate what we see in another cultural setting, but even more risk in believing that someone else can tell us what good teaching is all about: We have to discover this for ourselves. The Reggio Emilia educational project itself is a provocation to early childhood educators and researchers outside of Reggio Emilia, a challenge for us to look at our own cultural environments, values, and expectations to develop our own educational projects. Thus, what we are gaining from Reggio Emilia is passion for a process that acknowledges our need to engage in a cooperative journey with others, both children and adults. As a consequence, we need to think with great effort about our values and treasured beliefs and reflect more critically on our practices in early childhood education and curriculum.

In regards to values, early childhood education today is heavily framed and shaped by "the story of quality and high returns" (Moss, 2014, p. 3) infused by neoliberal thinking; this story projects "control and calculation, technology and measurement" (Moss, p. 3) and governs our thoughts and actions. Educational institutions look for what works to make schooling more effective and measurable (Biesta, 2006). Central to the story of quality and high returns is that learning has to do with the acquisition of something external, attempting to "acquire, to master, to internalize, or any other possessive metaphors we can think of” (Biesta, 2006, p. 27). Gert Biesta (2006) argues that "education is not just about the transmission of knowledge, skill, and values, but is concerned with the individuality, subjectivity, or personhood of the student, with their 'coming into the world' as unique, singular beings" (p. 27). Biesta suggests that "the educational responsibility today has to do with the 'creation' of worldly space, a space of plurality and difference, a space where freedom can appear and where singular, unique individuals can come into the world" (p. 100).

Accordingly, the purpose of this article is to respond to the question of what it might mean to create such a space as an alternative story about early childhood curriculum. I do this through engaging with the philosophical concepts of rhizome and transcendental empiricism of Deleuze and Guattari and progettazione of the Reggio Emilia approach, which offer new possibilities, potentials, and differences in early childhood curriculum making.

\section{Research context and participants}

I conducted this study in a childcare centre on the campus of a university in British Columbia located on the traditional and ancestral territories of the Squamish and Tsleil-Waututh Nations of the Coast Salish people. The philosophy of the childcare centre is inspired by the Reggio Emilia approach. I employed a qualitative research approach. My primary method was that of case study using participant observation and a pedagogy of listening as research tools. The study design was exploratory, descriptive, and interpretive in nature. I explored in this case study the connections and relationships children created over the four-month period of a project we called "the forest project." Using children's own ideas, narratives, and desires as the essential pathways winding through their experiences with a project, I investigated children's emerging ideas and understandings as they explored phenomena and interacted with each other. The forest project began with teachers noticing that the children had created special connections and relationships to some places in the nearby forest. These encounters within the forest became a starting point for the project. The forest project consists of five events. For this article, I extracted data from one of the events, "Flight of Leaves," and explored the children's ideas and narratives and examined the pedagogical relations in the processes of experimentation. In the case study, I worked with four-year-old children. In particular, Sarah, Ella, Tina, and Hailey (pseudonyms) were the main participants in this event. 


\section{Participant observation and pedagogy of listening}

The aim of participant observation is "to learn about the other by participating in his or her everyday life" (Warming, 2005, p. 51). According to Hanne Warming (2005), the participant observation method has great potential for listening well to children because it allows researchers to observe children's interactions with each other, with their teachers, and with their physical surroundings.

In this study, listening played a significant role. There are different ways in which researchers employ listening as a method (Clark, Kjørholt, \& Moss, 2005). Researchers use listening as a tool to learn about children and their culture. Researchers also use listening as a way to give voice to children, part of the basic ethos of the childhood research paradigm (Christensen \& James, 2000; James et al., 1998). Warming (2005) states: "The democratic ethos of giving voice is a powerful philosophy in social and pedagogical work with children in Europe" (p. 52), and listening carefully to children is at its heart. Warming points out the distinction

that listening as a tool and listening as constituting a basic ethos of giving voice are not necessarily the same, and may even be in conflict with each other. Giving voice involves listening, whereas listening does not necessarily involve giving voice. Listening as a tool requires hearing and interpreting what you hear, whereas giving voice further requires "Ioyal" facilitation and representation, making a common cause with the children. (p. 53)

These two different characteristics of listening played important roles in this study, first in understanding and explicating young children's perspectives and experiences, and second in exploring the role children's thoughts and narratives play in children's learning processes. By employing a "pedagogy of listening" (defined by Rinaldi, 2006, p. 65) to attend to young children's ideas and narratives, I sought to understand the ways children generate hypotheses and build their theories, both critical processes in children's learning. According to Rinaldi (2001),

understanding means being able to develop an interpretive theory, a narrative that gives meaning to the world around them ... these theories are extremely important in revealing how children think, question and interpret reality, and their own relationships with reality and with us. (p. 2)

Dahlberg and Moss (2005) echoed this belief when they stated, "listening to thought is about being able to hear the ideas and the theories of the Other, and to treat them seriously and with respect, neither ignoring them nor dismissing them for not providing the right answer" (p. 99).

According to Rinaldi (2006), "listening is an active verb, which involves giving an interpretation, giving meaning to the message and value to those who are being listened to by others" (p. 65). Listening means being open to the other and recognizing the other's differences from one's own position and experiences. It means "listening to thought— the ideas and theories, questions and answers of children — and struggling to make meaning from what is said, without preconceived ideas of what is correct or valid or appropriate" (Dahlberg \& Moss, 2005, p. 100). This perspective accords children their autonomy, and it does so by looking at them as the direct and primary entity of study (Greene \& Hogan, 2005). I used a pedagogy of listening to welcome and respect alterity in children's thinking and to open up new possibilities for approaching teaching and learning in early childhood education and practice.

\section{Flight of leaves event}

The flight of leaves event helps us to understand both children's learning as continual engagement with phenomena and people, and learners and the world as entangled becomings. Our relation to the world is a relationship as beings that are a part of the world (Barad, 2007). As the forest project unfolded, the children had many opportunities to engage with various leaves. I listened to children's unique perspectives on the world as they communicated 
their delight and wonderment about leaves. The flight of leaves event shows the process of how thoughts were created through encounters and relations; how the children became-with drawings, experiments, each other, and material realities; and how the teacher and the researcher responded to and became entangled "in an intertwined relationship of intra-activity with other matter and the children” (Lenz Taguchi, 2010, p. 4).

\section{Children's drawings and stories about leaves}

One morning, an educator brought different kinds of leaves and presented them on the table, along with white paper, coloured pencils, and pens. Children who were interested in exploring leaves freely could approach the table and explore leaves. Some children spent time touching, smelling, and examining the leaves and sharing their ideas. While the children were exploring leaves, the educator asked the children to tell us more about their thoughts. The following drawings and stories disclose the children's unique stories and perspectives about leaves.

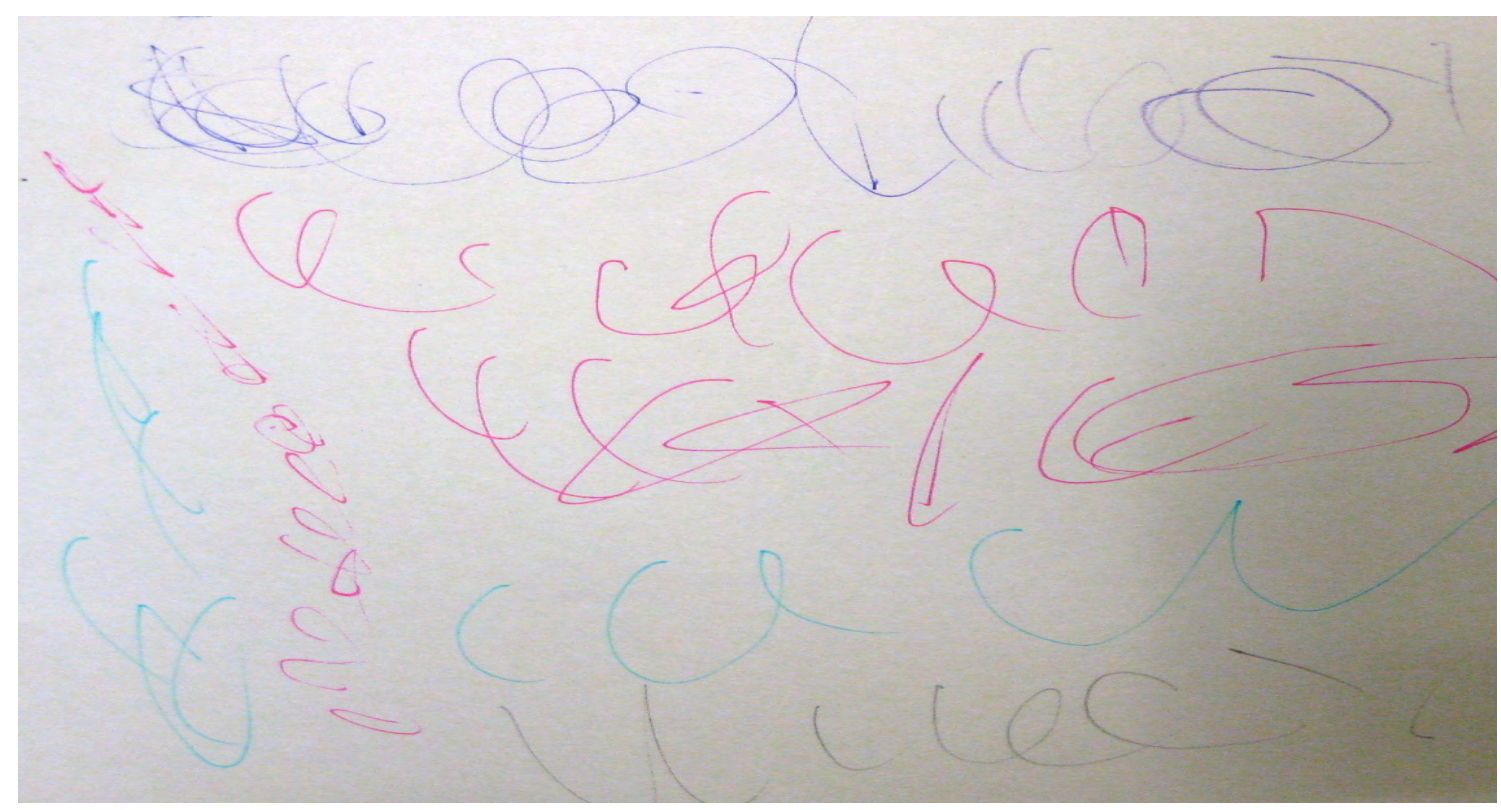

Figure 1. Sarah's drawing and story about dancing leaves.

Leaves grow into another tree.

Little tiny tree came out from somebody's house.

Tiny leaf came out and flew. There is a tree house playing music for the leaves.

When leaves falling down, the music comes from the tree house. It is a magic forest. The music comes from the tree house. This magic tree has flowers. This is the flower plays music for leaves.

When music comes out, leaves dance. These are monster leaves. They are dancing monster leaves. They are nice green monster leaves. 


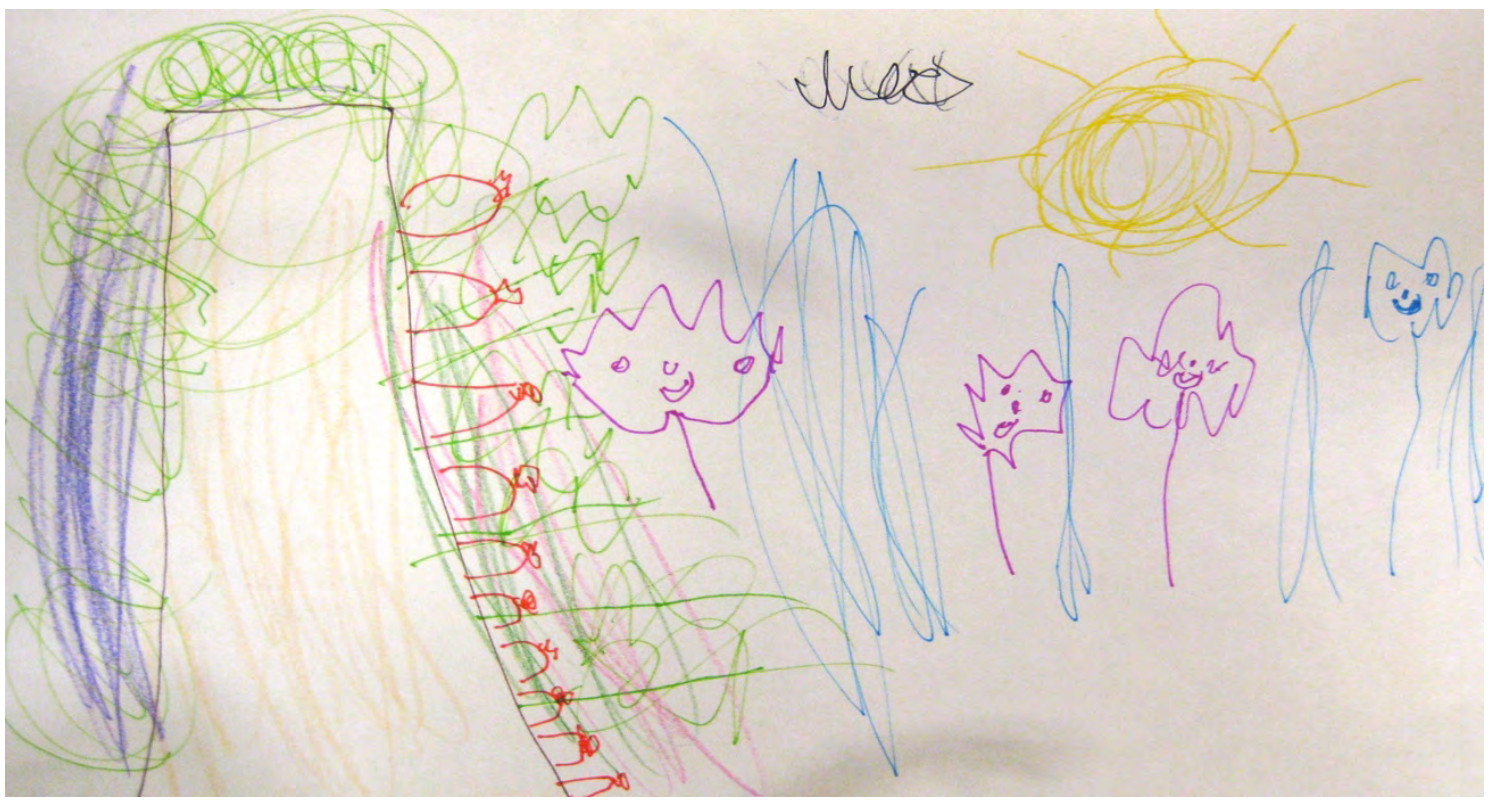

Figure 2. Ella's drawing and story about falling leaves.

This is a tree and these are dancing leaves.

These leaves are falling down to the ground. But they don't get hurt because they don't have skin.

When things fall down, they get hurt or broken. When leaves fall, they are beautiful.

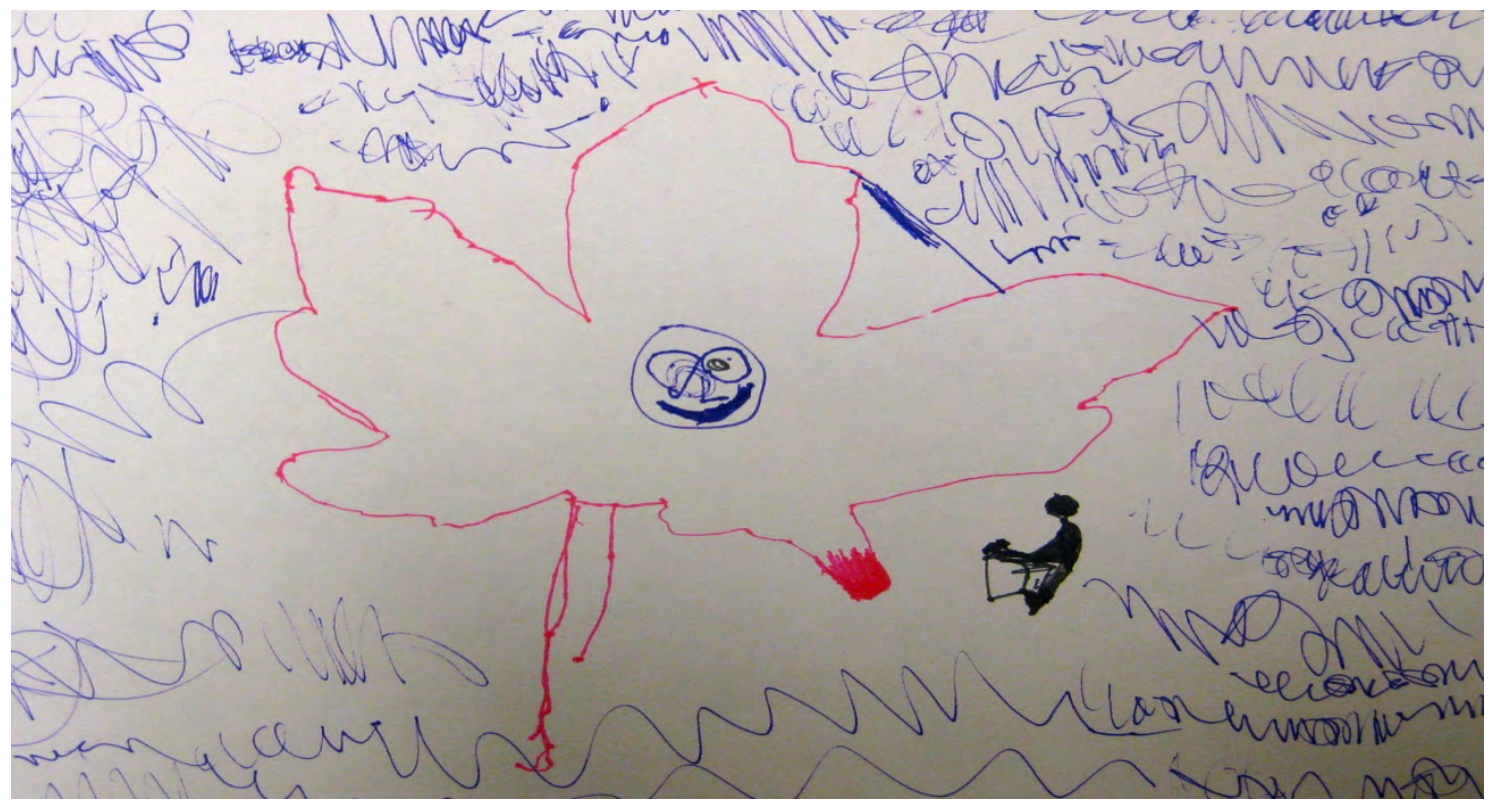

Figure 3. Hailey's drawing and story about maple leaves and a bird.

These are maple leaves. I love maple tree. There are lots of maple leaves at my house.

Leaf has sound. You can hear the sound if you tap on the leaf. 
Leaf sounds like a bell, rainbow, woodpeckers, and someone knocking on the door.

Leaf makes different sound. The sound is like a song.

The bird can hear leaves and leaves can hear bird.

Tree can hear leaves song and other leaves can hear the song.

Only woodpecker can hear leaves. And leaves think about flying on the bird.
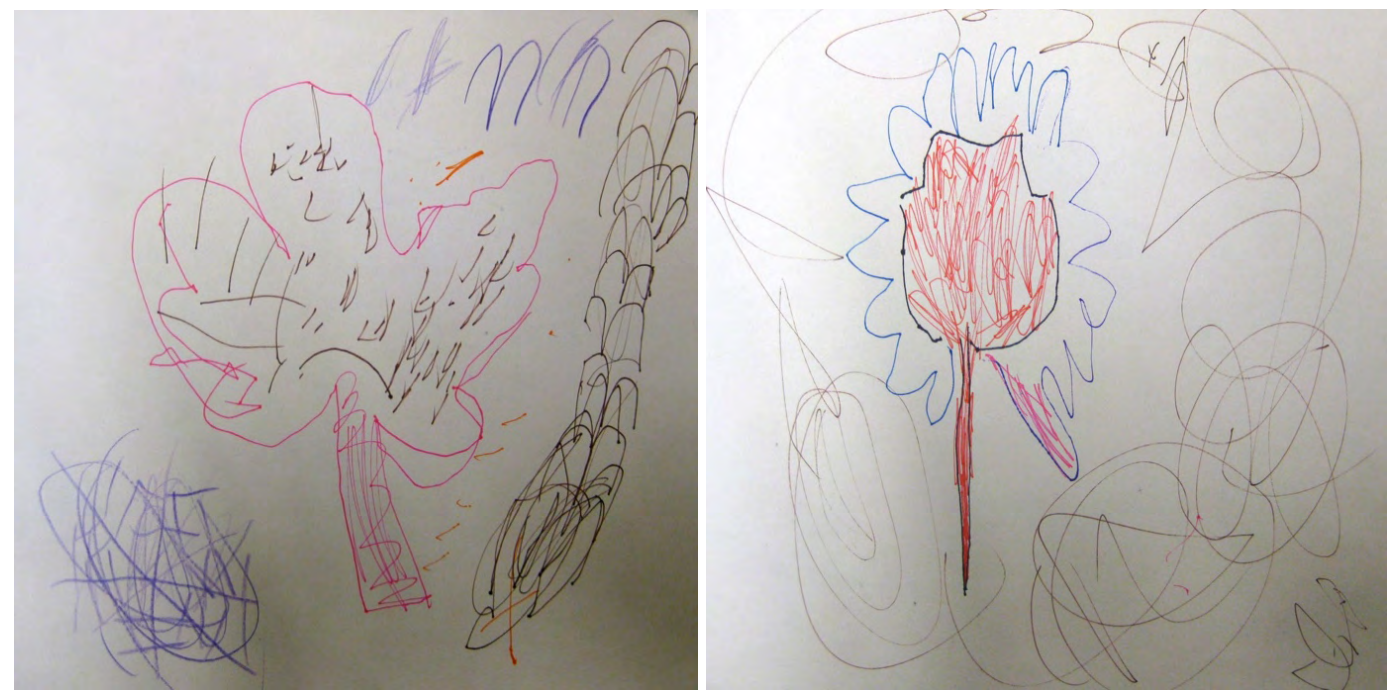

Figure 4. Venice's drawing and story about prince and princess leaves.

This is prince leaf and this is princess leaf.

How do they see each other? If you flip over the paper, they can see each other. They look each other in between area. And when there is music, a prince leaf and a princess leaf dance together.

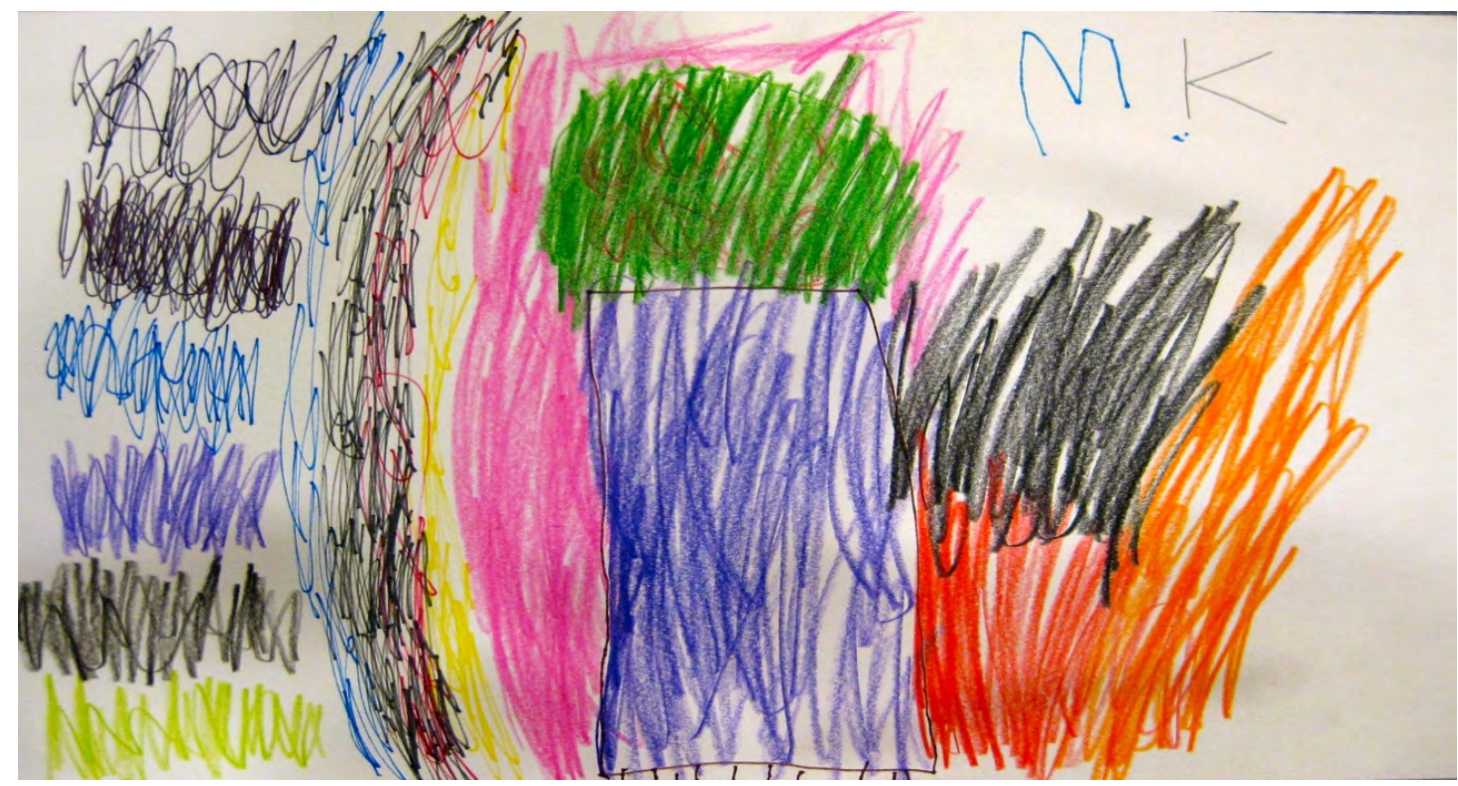

Figure 5. Tina's drawing and story about apples and leaves. 
These are magic apples on this tree.

Apples are inside of leaves.

When the leaves die, the apples come out.

According to Louise Cadwell (2003), the use of metaphors to transform reality and create other realities through processes of allusion, substitution, and imaginative metamorphosis is a basic element of the creative process; it is at the same time one of the strategies young children use to explore the world. Such allusion, imagination, and creativity are evident in the children's stories related to leaves. In addition, I noticed that the children made connections between their imaginative ideas about leaves and their lived experiences in the forest. These connections helped the children's imaginative stories unfold. Leaves provided opportunities for them to create stories and share multiple perspectives and ideas. For me, their drawings opened doors to the complexity of the children's encounters within the forest. In particular, Sarah's and Ella's ideas about falling leaves caught our attention and provoked us to know more. We arranged another drawing exploration.

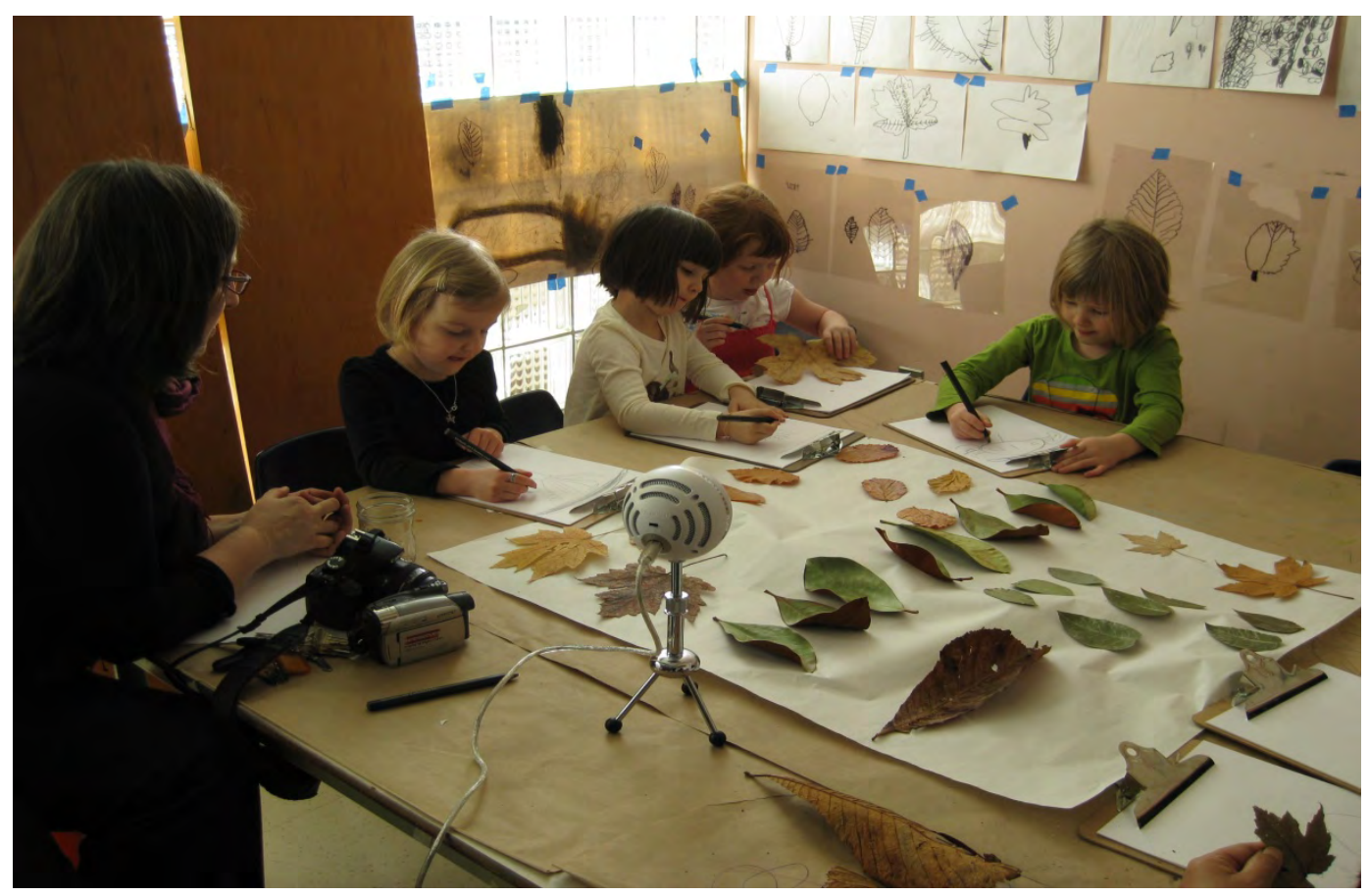

Figure 6. The children exploring and drawing leaves in the studio.

\section{Flight of leaves experiments}

The children observed and drew some of leaves that were displayed on the table. The leaves displayed were not passive materials. Leaves existed as performative agents of power; they affected children's thinking and altered their ongoing intra-actions (Barad, 2007). Karen Barad suggests that it is not only humans that have agency; all matter has possibilities of intervening and acting upon others. Thinking with Barad, I noticed that the children's meaning making and knowing were dependent on and "a result of process where the material and discursive are mutually implicated in the dynamics of intra-activity” (Barad, 2007, p. 152) 

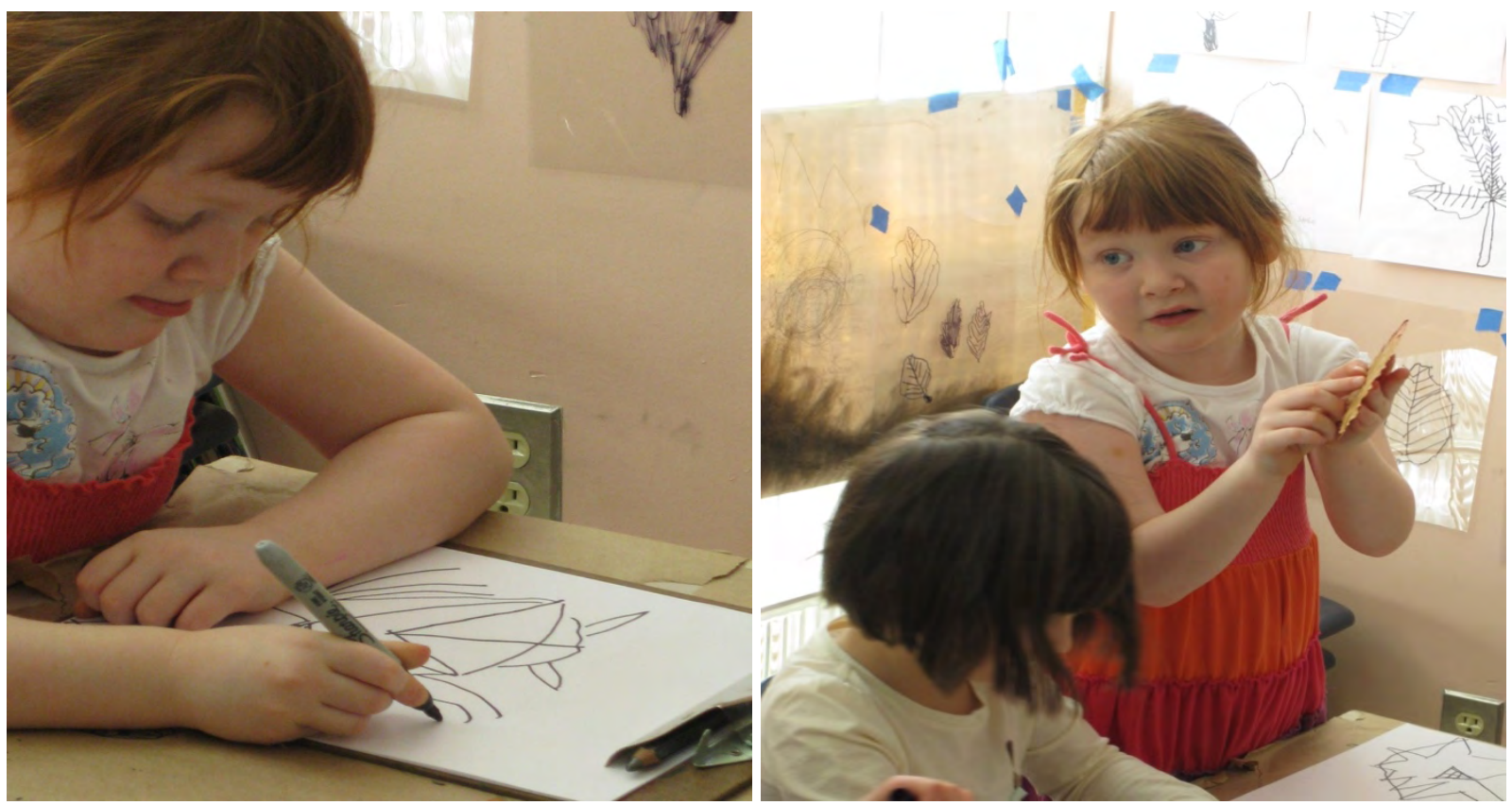

Figure 7. Sarah picked one of the leaves and observed and drew it for a while.

Look at my leaf.

My leaf is spreading out.

A leaf grows on the tree and roots grow too. So the leaf is attached to the tree.

A leaf has roots attached to the tree and when it is fall, the leaffalls down from the tree.

These are the roots spreading out and attached to the tree.
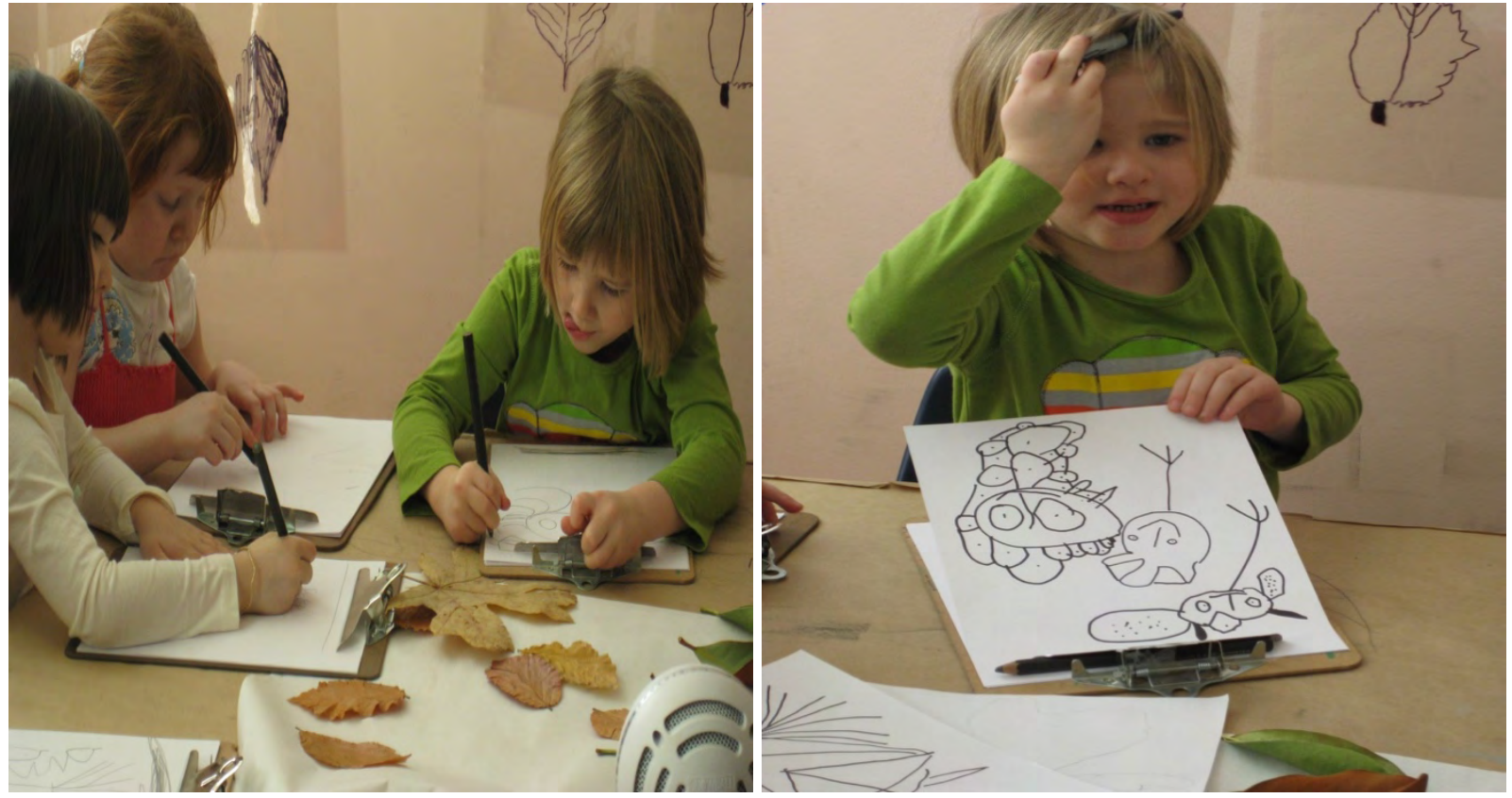

Figure 8. Hailey explained her drawing. 
All the leaves are bunched together, holding hands and falling down all together.

They are exercising together.

The children theorized about falling leaves. Ella described them as dancing. Sarah added that "when music comes out, leaves dance." Venice illustrated that "when there is music, a prince leaf and a princess leaf dance together." Hailey adapted the notion, saying, "leafs are falling down all together because they are exercising together." This thinking resituates knowing not as an act of humans; rather, knowing refigures the world entangled in a web of discursive, cultural, political and material forces (Lenz Taguchi, 2010).

Hailey held a leaf high and dropped it, then repeated her action with another leaf. She then dropped a small group of leaves at the same time. The leaves made beautiful lines when they were falling. The other children got excited and wanted to join Hailey's experiment. Soon, the children figured out that the leaves fell down too quickly for them to see their movements. Hailey wanted to climb onto the table so that she could see more. The other children were excited about the idea, so they took turns. The children tried dropping every leaf from their perch on the table, excited about the various lines of flight the different leaves made:

This one twirls. Did you see that?

That was really neat.

I want to see how this one goes.

This one moves like this. (using finger to express the movement)

Can you try this one? I will try this one.

Did you see how that one goes?

It went like dadadadada ...

I am having fun ... 

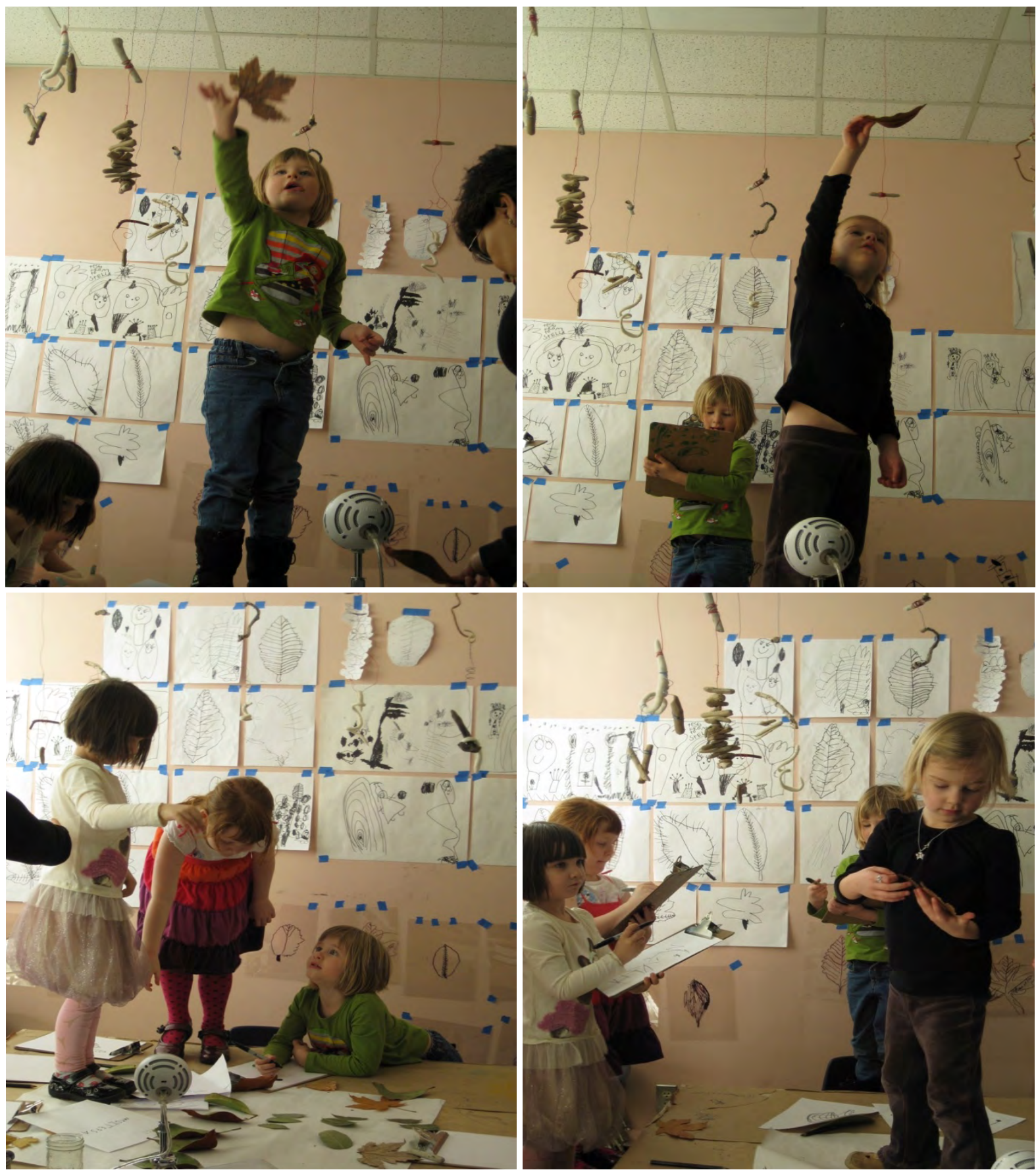

Figure 9. The children are watching different lines of flight made by each leaf.

The children expressed the flights of leaves with words and gestures. The teacher suggested the children draw the movements on white paper she tacked to the wall. First, the children drew the lines of flight with black pencils, but they realized they couldn't represent the paths of multiple leaves that way, so they asked for different colours. 

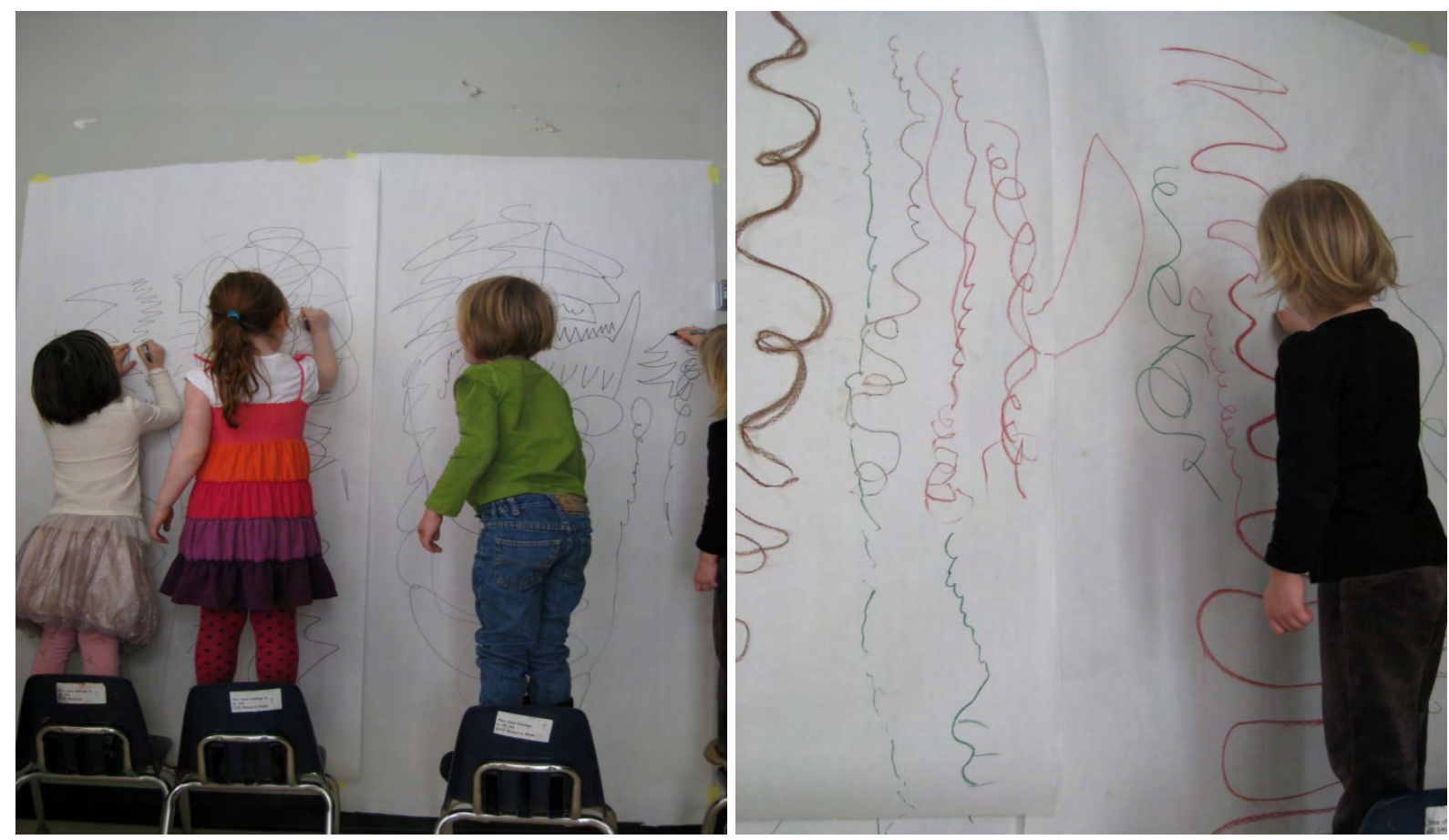

Figure 10. The children sharing their ideas on the movements of leaves by drawing them on the big piece of paper.

When Ella suggested they needed even more height from the ground to follow a leaf's path, the children found the highest table in the studio from which to drop leaves. The teacher and I suggested moving the experiments outside. A high wall formed a perfect backdrop for the falling leaves to create shadows as they fell, and a breeze added to their motion. The children were entranced watching the leaves flying, twirling, fluttering, flipping, falling, and landing.

Ella: We are ready, go!

Sarah: It is beautiful.

Tina: It is so lovely.

Hailey: Are you ready for this?

Are you ready for this small one?

Ella: Are you ready for this funny one?

Are you ready for this skinny one?

Ready steady go. Watch!

(They flew the leaves one by one, and they flew a bunch of them together.)

Ella: Ready steady go.

Hailey: Ready steady go.

Ella: Ready steady go ... 
Sarah: I am in the leaf rain. (Sarah stood at the bottom of the wall covered with leaves.)

Tina: We want more leaf rain.

\section{(Giggling)}

Sarah: We are in the leaf rain.

Tina: I see the leaf shadow.

Sarah: Can you catch the shadow?

Tina: Yes, I can catch the shadow. Look at this. I am holding a leaf and my shadow caught the shadow of leaf. Hahaha!
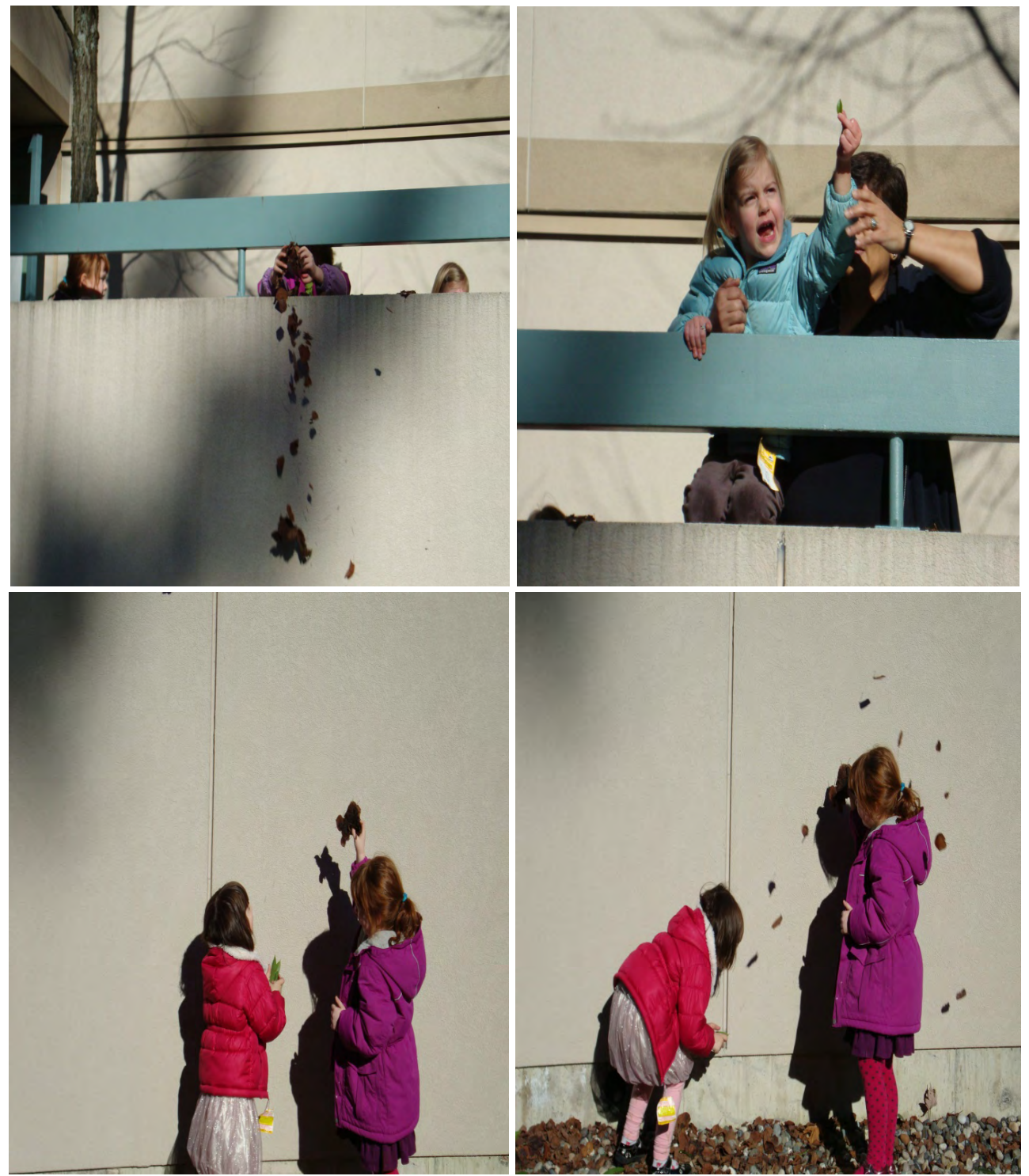

Figure 11. The children's experiments with flights of leaves outside the studio. 
Watching flights of leaves became a game to play and a song to sing. The children and adults got caught up in the desire for flying and falling leaves. The white wall that people passed by daily without noticing became a stimulating place. We altered the place. The place also changed the way of living in the space. It created unanticipated connections between the children, the children and the teachers, the children and the leaves, light and shadow, and leaves and wind. This space suddenly became alive, inviting us to interact with it. We were all protagonists in the event, entangled in the process of becoming. According to Deleuze (2004), the world is made of events. Events are happenings and becomings rather than things. Events are processes rather than substances. In my study, the children's learning was made of a series of events. Their learning evolved through encounters with ideas, materials, and surroundings rather than preplanned activities. Thus, it was becoming rather than completion of activities. This experience made me realize that researching and learning with children means not only listening to children but also bringing ourselves into the process of learning, a process of becoming.

When we encouraged the children to closely observe and explore leaves and their surroundings, the children inspired us to see leaves in a different way, in ways we could not if we relied on our own perspectives. The children created relations between the world and ourselves, making connections between each leaf and the height of a fall, its weight, speed, shape, and its interaction with the wind. Learning became a collaborative process between the children and the line of flight of each leaf, with questions arising in the event. Learning was not reduced to following linear paths in a standardized and preplanned curriculum. The children worked with their own curiosities and desires and were intrigued by each other's questions, ideas, and different ways of approaching the leaves.

\section{Concluding thoughts}

Deleuze's concept of transcendental empiricism provides an interesting way to view this event. The flight of leaves experiment demonstrates the importance of providing space where children can develop their own ideas, experiment with emerging questions, and invent new ways of thinking. The children discovered that each leaf made a unique line of flight, and they became curious about how height would influence these patterns. Their desire to see more movement led us to conduct the experiment outside the studio. The children discovered that wind could change lines of flight. I became more attentive to our surroundings as one of the adults who could enrich children's learning through supporting their ideas, rather than transmitting my own. I found the values of openness and spontaneity through the experience: If we allow children to lead us with their own ideas and curiosities, we are also able to create new ways of learning. In the flight of leaves event, learning was a process of working with problems and discovering something new. There was a flow or multiplicity of experiences from which any being or idea can be affected (Colebrook, 2002). Deleuze's transcendental empiricism brings forward a new conception of subjectivity; instead of seeing subjectivity as attached to a specific identity, subjectivity is viewed as a process of becoming. Through watching the leaves, I saw myself changing through a process of learning. I saw the children transforming my experience. The experiments affected the children and they responded with more experimentation. According to Colebrook (2002), Deleuze's transcendental empiricism helps us see this kind of interaction as part of the flow of experience.

Deleuze's emphasis on experience that is not grounded in a privileged subject provides us with new ways of understanding learning. Learning is about the process of becoming through experience. In my study, the children experimented based on ideas that emerged from their observations of falling leaves (and dancing leaves and exercising leaves). Their learning came through production of the intra-actions (defined by Barad, 2008) that took place through experiments. Learning does not end at a certain point. It keeps evolving with new connections and new ideas. Learning is becoming, rather than recognizing and representing recycled knowledge over and over again. Learning creates possibilities for new transformations, new lines of flight (Deleuze \& Guattari, 1987). 
The flight of leaves experiment demonstrates the creation of what Biesta (2006) refers to as a "worldly space, a space of plurality and difference, a space where freedom can appear and where singular, unique individuals can come into the world" (p. 100). Thoughts were created as the participants (children, educators, materials, wind, white wall, etc.) moved through encounters and relations, allowing educators and scholars to envision a world as a way to practice a worldly form of inclusion and as an opportunity for learning with others (Dahlberg \& Moss, 2013). In this event, the children experimented with ideas that emerged from their observations of falling leaves (and dancing leaves and exercising leaves). Their concepts and stories came through material-discursive knowledge production and rhizomatic connections that took place through experiments and did not end at a certain point. Through the process of experimentation, we found out how something works together through encounters and relations among parts of assemblages - their structures, flows, and connections (Deleuze \& Guattari, 1987). The children discovered that each leaf made a unique line of flight and they became more curious about how the material world would influences these patterns. Children's desire to see the leaves falling from a greater height led us to conduct the experiment outside the studio. The children developed their own ideas, experimented with emerging questions, and invented new ways of thinking. By listening to the children, the teacher and I shifted our perspectives on materials and became aware of how materials act upon thoughts and create concepts. The teachers and the researcher became co-inquirers with the children, being aware of intra-activities taking place in learning events between children and materials. Through working with materials and surroundings, children were able to take their thinking further and express themselves in unanticipated ways. This perspective has implications for education as a generative practice, creating worldly space (Biesta, 2006) that transforms children, adults, and our relations to and of the world. This transformation occurs through attending to children's relations with others and more-than-human life.

In this flight of leaves event, thoughts kept evolving with new connections and new ideas, creating possibilities for new transformations, new lines of flight. In this regard, Deleuze's concept of transcendental empiricism has great potential to transform early childhood curriculum inquiry, allowing those making the inquiry to welcome uncertainty, wonder, unpredictability, surprise, and amazement.

\section{Note}

This article is an original work by the author, Dr. Bo Sun Kim. The University of British Columbia Behavioural Research Ethics Board provided ethical approval for this study. The fieldwork was covered by UBC Ethic Certificate number H11-00305. Written informed consent was obtained from parents / legally authorized guardians and a teacher for publication of the accompanying images and identifying information. 


\section{References}

Barad, K. (2007). Meeting the university halfway: Quantum physics and the entanglement of matter and meaning. Durham, NC: Duke University Press.

Barad, K. (2008). Posthumanist performativity: Toward an understanding of how matter comes to matter. In S. Alaimo \& S. Hekman (Eds.), Material feminisms (pp. 120-154). Bloomington: Indiana University Press.

Baugh, B. (2010). Death. In P. Adrian (Eds.), The Deleuze dictionary (pp. 93-94). New York, NY: Columbia University Press.

Biesta, G. J. J. (2006). Beyond learning: Democratic education for a human future. Boulder, CO: Paradigm.

Cadwell, L. (2003). Bringing learning to life. New York, NY: Teachers College Press.

Christensen, P., \& James, A. (Eds.). (2000). Research with children: Perspectives and practice. London, UK: Falmer Press.

Clark, A., Kjørholt, A. \& Moss, P. (Eds.). (2005). Beyond listening: children's perspectives on early childhood services. Bristol, UK: Policy Press.

Colebrook, C. (2002). Gilles Deleuze. London, UK: Routledge.

Dahlberg, G., \& Moss, P. (2005). Ethics and politics in early childhood education. New York, NY: RoutledgeFalmer.

Dahlberg, G., \& Moss, P. (2009). Foreword. In L. M. Olsson (Author), Movement and experimentation in young children's learning: Deleuze and Guattari in early childhood education (pp. xiii-xxviii). London, UK: Routledge.

Dahlberg, G., \& Moss, P. (2013). Introduction by the series editors. In A. Taylor (Author), Reconfiguring the natures of childhood (pp. viii-xii). London, UK: Routledge.

Dahlberg, G., Moss, P., \& Pence, A. (2013). Beyond quality in early childhood education and care: Languages of evaluation (3 ${ }^{\text {rd }}$ ed.). London, UK: Falmer Press.

Deleuze, G. (1988). Spinoza: Practical philosophy (R. Hurley, Trans.). San Francisco, CA: City Light Books.

Deleuze, G. (1994). Difference and repetition (P. Patton, Trans.). New York, NY: Columbia University Press.

Deleuze, G. (2004). The logic of sense (L. Mark, Trans.). London, UK: Continuum.

Deleuze, G., \& Guattari, F. (1987). A thousand plateaus: Capitalism and schizophrenia (B. Massumi, Trans.). Minneapolis: University of Minnesota Press.

Duckworth, A. D. (2009, September 30). An exploration of Deleuze and Guattari's concept of the rhizome. The Motley View: The Journal of Film, Art, and Aesthetics. Retrieved from https://ardfilmjournal.wordpress.com/2009/09/30/brief-exploration-of-the-concept-ofthe-rhizome/

Edwards, C., Gandini, L., \& Forman, G. (2012). The hundred languages of children: The Reggio Emilia experience in transformation (3 ${ }^{\text {rd }}$ ed.). Santa Barbara, CA: Praeger.

Gandini, L., \& Kaminsky, J. (2006). The construction of the educational project: An interview with Carlina Rinaldi. In C. Rinaldi (Author), In dialogue with Reggio Emilia: Listening, researching, and learning (pp. 121-136). New York, NY: Routledge.

Goldhaber, J. (2008). To Italy and back: A teacher education program's journey. In L. Gandini, S. Etheredge \& L. Hill (Eds.), Insights and inspirations from Reggio Emilia: Stories of teachers and children from North America (pp. 176-179). Worcester, MA: Davis.

Greene, S., \& Hogan, D. M. (2005). Researching children's experience: Approaches and methods. Thousand Oaks, CA: SAGE.

James, A., Jenks, C. \& Prout, A. (1998). Theorizing childhood. New York, NY: Teachers College Press.

Lenz Taguchi, H. (2010). Going beyond the theory/practice divide in early childhood education: Introducing an intra-activity pedagogy. London, UK: Routledge. 
Malaguzzi, L. (1998). History, ideas, and basic philosophy: An interview with Lella Gandini. In C. Edwards, L. Gandini, \& G. Forman (Eds.), The hundred languages of children: The Reggio Emilia approach-Advanced reflections (2 ${ }^{\text {nd }}$ ed.; pp. 49-97). Greenwich, CT: Ablex.

Moss, P. (2014). Transformative change and real utopias in early childhood education: A story of democracy, experimentation, and potentiality. London, UK: Routledge.

Moss, P., \& Petrie, P. (2002). From children's services to children's spaces: Public policy, children, and childhood. London, UK: RoutledgeFalmer.

New, R. (2007). Reggio Emilia as cultural activity theory in practice. Theory into Practice, 46(1), 5-13. https://doi.org/10.1080/00405840709336543

Olsson, L. M. (2009). Movement and experimentation in young children's learning: Deleuze and Guattari in early childhood education. London, UK: Routledge.

Rinaldi, C. (1998). Projected curriculum constructed through documentation-progettazione: An interview with Lella Gandini. In C. Edwards, L. Gandini, \& G. Forman (Eds.), The hundred languages of children: The Reggio Emilia approach-Advanced reflections $\left(2^{\text {nd }}\right.$ ed.; pp. 113-125). Greenwich, CT: Ablex.

Rinaldi, C. (2001). Documentation and assessment: What is the relationship? In C. Giudici, C. Rinaldi, \& M. Krechevsky (Eds.), Making learning visible: Children as individual and group learners (pp. 78-89). Reggio Emilia, Italy: Reggio Children.

Rinaldi, C. (2006). In dialogue with Reggio Emilia: Listening, researching, and learning. New York, NY: Routledge.

Semetsky, I. (2007). Semi-analysing events: Towards a cultural pedagogy of hope. Studies in Philosophy and Education, 26, 253-265. http://dx.doi.org/10.1007/s11217-007-9030-x

Warming, H. (2005). Do other children in foster care feel the same way as I do? Copenhagen: Frydenlund.

Zhang, Y. (2012). A critical review of immigrant children's literacies and identities from a Deleuzian perspective. Journal of Contemporary Issues in Education, 7(1), 24-46. Retrieved from https://journals.library.ualberta.ca/jcie/index.php/JCIE/article/view/18079/14240 